\title{
HIGH-FREQUENCY DISTORTION PRODUCT OTOACOUSTIC EMISSIONS MEASURED BY TWO SYSTEMS: AN EXAMPLE OF A SUBJECT WITH NORMAL HEARING
}

\author{
Edyta Pilka', W. Wiktor Jedrzejczak ${ }^{1}$, Lukasz Olszewski ${ }^{1}$, Henryk Skarzynski ${ }^{2}$ \\ ${ }^{1}$ Department of Experimental Audiology, World Hearing Center, Institute of Physiology and Pathology of \\ Hearing, Warsaw/Kajetany, Poland \\ ${ }^{2}$ World Hearing Center, Institute of Physiology and Pathology of Hearing, Warsaw/Kajetany, Poland \\ Corresponding author: Edyta Pilka, World Hearing Center of the Institute of Physiology and Pathology of \\ Hearing, Mokra 17 Str., Kajetany, 05-830 Nadarzyn, e-mail: e.pilka@ifps.org.pl
}

\begin{abstract}
Background: Distortion product otoacoustic emissions (DPOAEs) are most commonly measured up to $6 \mathrm{kHz}$. However, there are now systems available that can measure DPOAEs up to $16 \mathrm{kHz}$. The purpose of this study was to compare two such systems.

Case report: One subject with hearing thresholds below $20 \mathrm{~dB} \mathrm{HL}$ at frequencies from 0.125 to $16 \mathrm{kHz}$ was used to compare DPOAEs measured by the two systems. The HearID+DP (Mimosa Acoustics) and SmartDPOAE (Intelligent Hearing Systems) were used. DPOAEs were measured at frequencies from 0.5 to $16 \mathrm{kHz}$. Short-time repeatability was assessed by comparing DPOAE amplitudes between two measurements, with the second measurement made after refitting the probe. DPOAEs were above the noise for all tested frequencies. Comparison of results from the two systems showed that the differences between consecutive measurements and between the two systems was lowest in the $1-8 \mathrm{kHz}$ range and highest in the 9-16 kHz range. However, even in the $1-8 \mathrm{kHz}$ range, differences between response levels averaged $4 \mathrm{~dB}$.
\end{abstract}

Conclusions: Both systems provided DPOAE levels that were consistent with normal hearing thresholds. However, the differences between the two systems were quite high and may be too large to detect small changes in cochlear status if different equipment is used.

Key words: distortion product otoacoustic emissions $\bullet$ DPOAE $\bullet$ high frequency

\section{MEDICIÓN DE EMISIONES OTOACÚSTICAS POR PRODUCTOS DE DISTORSIÓN PARA LAS ALTAS FRECUENCIAS MEDIANTE DOS DISPOSITIVOS: ESTUDIO DEL CASO DE UNA PERSONA CON LA AUDICIÓN SANA}

\section{Resumen}

Introducción: La medición de emisiones otoacústicas por productos de distorsión (EOAPD) abarca habitualmente las frecuencias de hasta $6 \mathrm{kHz}$. Gracias a nuevos sistemas de medición, el registro de EOAPD puede ampliarse a incluso $16 \mathrm{kHz}$. El objetivo del presente trabajo fue comparar los dos dispositivos de este tipo.

Descripción del daso: En el estudio en el que se han utilizado dos sistemas de medición de EOAPD: HearID+DP (Mimosa Acoustics) y SmartDPOAE (Intelligent Hearing Systems) participó una persona cuyos umbrales de audición no excedían los $20 \mathrm{~dB}$ HL para las frecuencias de 0,125-16 kHz. La medición de EOAPD abarcaba las frecuencias desde 0,5 hasta $16 \mathrm{kHz}$. La repetitividad de los resultados en el intervalo corto entre las mediciones consecutivas se evaluó en base a la diferencia de amplitudes de EOAPD para dos mediciones, de las cuales la segunda se realizaba tras aplicar otra vez la sonda auditiva. Para todas las frecuencias registradas, las EOAPD estaban por encima del ruido de fondo. La comparación entre resultados de los dos sistemas de medición ha permitido observar que las diferencias mas pequeñas entre las sucesivas mediciones y resultados de cada dispositivo ocurrieron en el rango 1-8 kHz, y las más grandes en el rango 9-16 kHz. Aun así, en el primero de dichos rangos la diferencia media entre los niveles de respuesta era de $4 \mathrm{~dB}$.

Conclusiones: Ambos sistemas registraron respuestas de EOAPD conformes a los umbrales de audición correctos. Sin embargo, las diferencias entre los resultados registrados por ambos dispositivos eran relativamente grandes y podrían imposibilitar la detección de cambios sutiles desarrollados en la cóclea cuando las mediciones no se efectúan con el mismo dispositivo.

Palabras clave: emisiones producto de distorsiones resultantes del comportamiento no lineal de la cóclea • EOAPD • altas frecuencias 


\title{
ИЗМЕРЕНИЕ ОТОАКУСТИЧЕСКОЙ ЭМИССИИ НА ЧАСТОТЕ ПРОДУКТА ИСКАЖЕНИЯ ДЛЯ ВЫСОКИХ ЧАСТОТ ДВУМЯ УСТРОЙСТВАМИ: ИССЛЕДОВАНИЕ СЛУЧАЯ ЧЕЛОВЕКА С ПРАВИЛЬНЫМ СЛУХОМ
}

\section{Изложение}

Введение: Измерение отоакустической эмиссии на частоте продукта искажения (DPOAE) обычно касается частот до 6 кГц. Благодаря новым измерительным системам регистрацию DPOAE можно расширить даже до 16 кГц. Целью настоящей работы было сравнение двух устройств данного типа.

\begin{abstract}
Описание случая: В исследовании с использованием двух систем измерения ЭЧПИ (DPOAE) - HearID+DP (MimosaAcoustics) и SmartDPOAE (Intelligent Hearing Systems) - участвовал один человек, пороги слышимости которого не превышали 20 дБ HL (hearing level) для частоты 0,125-16 кГц. Измерение ЭЧПИ охватывало частоты с 0,5 по 16 кГц. Повторяемость результатов в коротком промежутке между измерениями оценивалась на основе разницы амплитуд DPOAE для двух измерений, второе из которых проводилось после повторной установки измерительного зонда. Для всех зарегистрированных частот DPOAE были выше шума. Сравнение результатов обеих измерительных систем позволило отметить, что самые маленькие различия между следующими друг за другом измерениями и результатами по каждому из устройств имели место в диапазоне 1-8 кГц, а самые большие - в диапазоне 9-16 кГц. Однако даже в первом из указанных дапазонов уровни ответов отличались в среднем на 4 дБ.
\end{abstract}

Выводы: Обе системы рарегистрировали ответы ЭЧПИ в соответствии с правильными порогами слышимости. Однако различия в результатах, регистрированных двумя устройствами, были относительно высокими и могут сделать невозможным обнаружение небольних изменений, происходящих в улитке, если измерения осуществляются не одним и тем же устройством.

Ключевые слова: отоэмиссия на частоте продукта нелинейного искажения улитки • ЭЧПИ (DPOAE) • высокие частоты

\section{POMIAR EMISJI OTOAKUSTYCZNYCH PRODUKTÓW ZNIEKSZTAŁCEŃ DLA WYSOKICH CZESTOTLIWOŚCI PRZEZ DWA URZĄDZENIA: STUDIUM PRZYPADKU OSOBY Z PRAWIDŁOWYM SŁUCHEM}

\section{Streszczenie}

Wstęp: Pomiar emisji otoakustycznych produktów zniekształceń (DPOAE) zazwyczaj obejmuje częstotliwości do 6 kHz. Dzięki nowym systemom pomiarowym, rejestrację DPOAE można rozszerzyć aż do $16 \mathrm{kHz}$. Celem niniejszej pracy było porównanie dwu tego typu urządzeń.

Opis przypadku: W badaniu z wykorzystaniem dwu systemów do pomiaru DPOAE - HearID+DP (Mimosa Acoustics) i SmartDPOAE (Intelligent Hearing Systems) - uczestniczyła jedna osoba, której progi słyszenia nie przekraczały 20 dB HL dla częstotliwości 0,125-16 kHz. Pomiar DPOAE obejmował częstotliwości od 0,5 do $16 \mathrm{kHz}$. Powtarzalność wyników w krótkim odstępie między kolejnymi pomiarami oceniano na podstawie różnicy amplitud DPOAE dla dwu pomiarów, z których drugi dokonywany był po ponownym umieszczeniu sondy pomiarowej. Dla wszystkich rejestrowanych częstotliwości DPOAE były powyżej szumu. Porównanie wyników z obu systemów pomiarowych, pozwoliło zaobserwować, że najmniejsze różnice między kolejnymi pomiarami i wynikami z każdego z urządzeń wystąpiły w przedziale 1-8 kHz, a największe w przedziale 9-16 $\mathrm{kHz}$. Jednakże nawet $\mathrm{w}$ pierwszym $\mathrm{z}$ tych przedziałów poziomy odpowiedzi różniły się średnio o $4 \mathrm{~dB}$.

Wnioski: Oba systemy zarejestrowały odpowiedzi DPOAE zgodne z prawidłowymi progami słyszenia. Jednakże różnice między wynikami rejestrowanymi przez oba urządzenia były stosunkowo wysokie i mogą uniemożliwić wykrywanie subtelnych zmian zachodzących w ślimaku gdy pomiary nie są wykonywane na tym samym urządzeniu.

Słowa kluczowe: otoemisje produktów zniekształceń nieliniowych ślimaka • DPOAE • wysokie częstotliwości 


\section{Introduction}

Distortion product otoacoustic emissions (DPOAEs) are important diagnostic tools for hearing [1]. One of the newest developments is the option to extend the usual range of measurement from the normal upper limit of $6-8 \mathrm{kHz}$ to $16 \mathrm{kHz}$ [2]. Despite the fact there are commercially available systems for such measurements the literature on this topic is not extensive.

The most important feature of any measurement is repeatability. In the case of DPOAEs it is known that they are most reliable in the range of $1-8 \mathrm{kHz}[3,4]$. Frequencies below $1 \mathrm{kHz}$ are usually less reliable and not as good in separating normally hearing ears from ears with hearing loss [5]. In the case of frequencies above $8 \mathrm{kHz}$, the repeatability is reported to be lower than for $1-8 \mathrm{kHz}$ [4]. However the reliability was still considered satisfactory.

Despite the fact that there are many different systems for measurement of OAEs, there are practically no reports that compare them. In the only comparison that has been made, the results from different groups of subjects were compared [6] and the differences between the systems were quite large.

The purpose of the present study was to compare results of DPOAEs measured over the range of $0.5-16 \mathrm{kHz}$ from two systems: HearId+DP and SmartDPOAE.

\section{Material and methods}

A case study is presented on a 29 -year-old woman. She was laryngologically healthy with no ear abnormalities observed in otoscopy. The subject was studied under calm conditions and was not exposed to excessive long-term or short-term noise prior to testing. She was tested in a sound-treated booth.

Normal middle ear function was determined by tympanometry using the clinical Madsen Zodiac 901 tympanometer (GN Otometrics). Tympanograms were recorded using a measurement frequency of $226 \mathrm{~Hz}$.

Pure tone audiometry was assessed using the Madsen Astera (GN Otometrics). Air conduction thresholds over the frequency range $0.125-8 \mathrm{kHz}$ were measured using TDH39 headphones, and over the frequency range 9-16 $\mathrm{kHz}$ with HDA 200 headphones. Bone conduction thresholds were measured over the frequency range $0.25-4 \mathrm{kHz}$ using a B-71 bone vibrator. Thresholds were better than 15 $\mathrm{dB} \mathrm{HL}$ at all frequencies from 0.125 to $16 \mathrm{kHz}$, except at $16 \mathrm{kHz}$ for the left ear where the threshold was $15 \mathrm{~dB}$ HL.

Auditory brainstem responses (ABRs) were also recorded. The morphology of the wave complex and intervals for waves I-III and III-V did not indicate any auditory nerve or brainstem dysfunction.

DPOAEs were measured in low ambient noise conditions using two systems: a HearID+DP system (Mimosa Acoustics, USA) running software version 5.1.3.0 and fitted with an ER-10C probe microphone (Etymotic Research, USA) and a SmartDPOAE system (Intelligent Hearing Systems,
USA) version 4.53 and with an ER-10B+ probe microphone (Etymotic Research, USA).

DPOAEs were evoked by two tones (denoted as $f_{1}$ and $f_{2}$ ) and responses were measured at a frequency of $2 f_{1}-f_{2}$. DPOAEs were measured at selected frequencies for $f_{2}$ of approximately $0.5,0.75,1,1.5,2,3,4,5,6,7,8,9,10,11,12$, 14 , and $16 \mathrm{kHz}$; the $f_{2} / f_{1}$ ratio was 1.2 and stimulus levels were 65 and $55 \mathrm{~dB}$ SPL. The other measurement settings used were the same as in some of the default protocols of the systems. It was not possible to set the exact same frequencies for both systems. Additionally, the HearID+DP system was equipped with a probe with foam ear tips, while the SmartDPOAE was equipped with silicone ear tips.

Each recording session consisted of the following measurements: Two measurements for the first system (a second measurement was made after taking out and refitting the probe - multiple-fit mode), then two measurements for the second system (again with the second measurement made after refitting the probe).

The subject gave written informed consent prior to participation. Research procedures were approved by the Ethics Committee of the Institute of Physiology and Pathology of Hearing, Poland.

\section{Results}

In Figure 1, DPOAE levels for $f_{2}$ frequencies from 0.5 to $16 \mathrm{kHz}$ are shown for both ears of one subject. Measurements from the two systems are shown. For both systems DPOAE response levels exceeded the noise over the whole frequency range. This result is consistent with normal hearing thresholds in this range. The response levels differed for different frequencies by as much as $20 \mathrm{~dB}$. There are two main maxima at $6 \mathrm{kHz}$ and $14 \mathrm{kHz}$. It can be seen that response levels were quite similar for frequencies up to $8 \mathrm{kHz}$. For higher frequencies, there are quite large differences between DPOAEs measured by the two systems.

Next, short-time repeatability was assessed in which the differences between measurements made by each system and between them were evaluated (Figure 2). For each system, the absolute difference was calculated between DPOAE response levels from the first and the second (after refitting the probe) measurement. Also differences between DPOAE response levels from HearID+DP and SmartDPOAE were calculated. To simplify the presentation, results were averaged across selected frequency ranges: for low frequencies $(0.5-0.7 \mathrm{kHz})$, middle frequencies $(1-8 \mathrm{kHz})$, and high frequencies $(9-16 \mathrm{kHz})$. From Figure 2 it can be seen that DPOAEs are more stable for middle frequencies $(1-8 \mathrm{kHz})$. Additionally, it seems that HearID+DP recordings are also more stable for low frequencies $(0.5-0.7 \mathrm{kHz})$. Generally, the differences at low and middle frequencies for the HearID+DP were quite small - less than $2 \mathrm{~dB}$. For SmartDPOAE and for middle frequencies, differences between the two measurements were less than $4 \mathrm{~dB}$; for lower frequencies they were higher, reaching $6 \mathrm{~dB}$ for the right ear. In the case of high frequencies $(9-16 \mathrm{kHz})$, the differences were highest, reaching $6.5 \mathrm{~dB}$ for the HearID+DP and $10 \mathrm{~dB}$ for the SmartDPOAE. The differences between DPOAEs from 

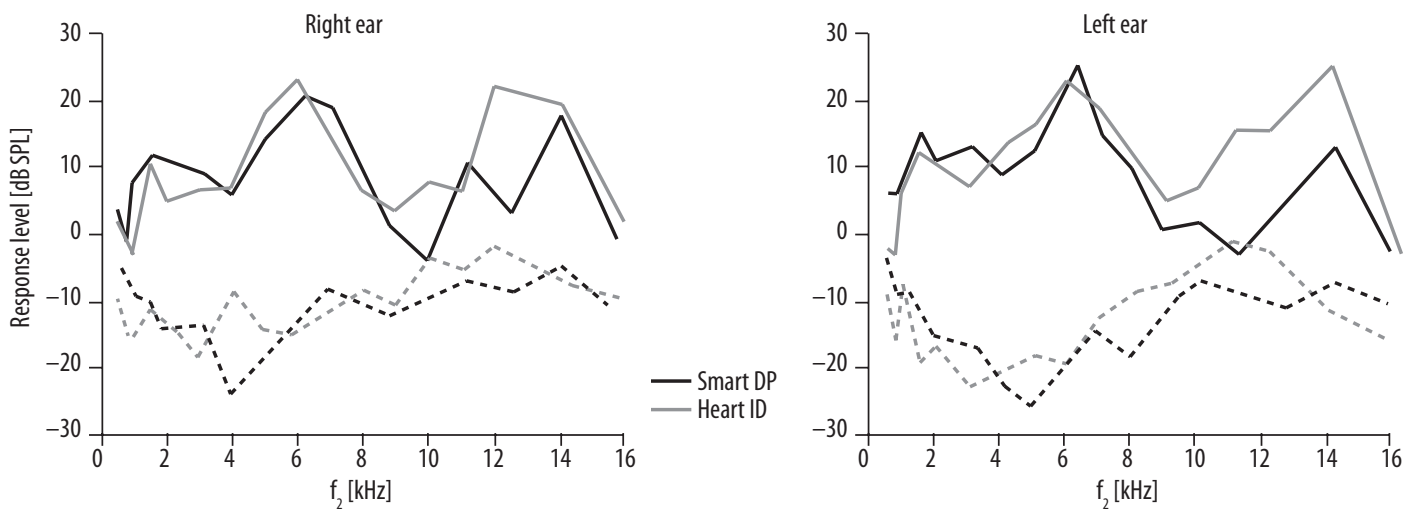

Figure 1. DPOAEs for one subject measured by the two systems. Response level - solid lines; noise level - dashed lines


Figure 2. Differences between DPOAE measurements before and after refitting the probe for SmartDP, HearID, and difference between measurements from these systems. Absolute values shown. Average difference for low frequencies $(0.5-0.7 \mathrm{kHz})$, for middle frequencies $(1-8 \mathrm{kHz})$, and high frequencies $(9-16 \mathrm{kHz})$ are shown

the two systems were generally slightly higher than between consecutive measurements made from each. Again, middle frequencies seemed the most reliable, with differences reaching $4 \mathrm{~dB}$. For high frequencies the difference reached close to $9.5 \mathrm{~dB}$.

\section{Discussion}

In general, comparison of DPOAE results from the two measurement systems for a single subject shows that the differences were quite high for low and very high frequencies. The best agreement was for middle-range frequencies of $1-8 \mathrm{kHz}$, but even here the difference was also rather high (up to $4 \mathrm{~dB}$ ). It might be too high to detect small changes in cochlear status when responses measured by each system are compared.

In terms of stability of the DPOAE responses for each system, it was quite good for middle frequencies but less satisfactory for lower and higher frequencies. This is in agreement with the previous studies that also indicated that DPOAEs for low $(<1 \mathrm{kHz})$ and high $(>8 \mathrm{kHz})$ frequencies are less reliable than in the middle range $[2,5]$.

The general characteristic of DPOAE responses is similar to average results from previous studies [2,7]. The signal is characterized by maxima for DPOAE response levels at 6 and $12-14 \mathrm{kHz}$. In the case studied, DPOAEs were consistent with pure tone audiometry. Hearing thresholds were better than $20 \mathrm{~dB}$ HL for all frequencies up to $16 \mathrm{kHz}$, and DPOAE response levels were higher than noise levels also up to $16 \mathrm{kHz}$.

There are several factors that influence DPOAE measurements besides equipment differences (e.g. different hardware/software, probes, ear tips). In addition, the position of the probe in the ear canal can also significantly affect DPOAEs, especially at higher frequencies [8]. The differences between the systems may also be influenced by the slightly different stimulus frequencies used, since it is known that the fine structure of DPOAEs has many peaks and valleys [9]. In this way, DPOAE amplitude may change significantly even over a few hertz.

\section{Conclusions}

Comparison of different systems for OAE measurements seems essential. It is likely that when a subject is tested in different clinics, different equipment will be used. The present results show that while, in general, the results from the two systems are in agreement over the middle frequency range, the differences between them may be too large to detect small changes in cochlear status. 


\section{References:}

1. Lonsbury-Martin BL, Whitehead ML, Martin GK. Clinical applications of otoacoustic emissions. J Speech Hear Res, 1991; 34(5): 964-81.

2. Pilka E, Jedrzejczak WW, Trzaskowski B, Skarzynski H. Variability of distortion product otoacoustic emissions at 10, 12, and $16 \mathrm{kHz}$ : A preliminary study. J Hear Sci, 2014; 4(4): 59-64.

3. Cacace AT, McClelland WA, Weiner J, McFarland DJ. Individual differences and the reliability of 2F1-F2 distortion-product otoacoustic emissions: Effects of time-of-day, stimulus variables, and gender. J Speech Hear Res, 1996; 39(6): 1138-48.

4. Dreisbach LE, Long KM, Lees SE. Repeatability of high-frequency distortion-product otoacoustic emissions in normal hearing adults. Ear Hear, 2006; 27(5): 466-79.
5. Gorga MP, Neely ST, Bergman BM, Beauchaine KL, Kaminski JR, Peters J et al. A comparison of transient-evoked and distortion product otoacoustic emissions in normal-hearing and hearing-impaired subjects. J Acoust Soc Am, 1993; 94(5): 2639-48.

6. Hall JW. Handbook of otoacoustic emissions. San Diego, CA: Singular Publishing, 2000.

7. Dunckley KT, Dreisbach LE. Gender effects on high frequency distortion product otoacoustic emissions in humans. Ear Hear, 2004; 25(6): 554-64.

8. Zebian M, Hensel J, Fedtke T, Vollbort S. Interpretation of distortion product otoacoustic emissions at higher frequencies. J Hear Sci, 2011; 1(3): 49-51.

9. Shaffer LA, Withnell RH, Dhar S, Lilly DJ, Goodman SS, Harmon KM. Sources and mechanisms of DPOAE generation: Implications for the prediction of auditory sensitivity. Ear Hear, 2003; 24(5): 367-79. 